\title{
Cikkismertetés: A hat- és hétéveseket célzó, elhízást megelőző iskolai programok hatékonyságának randomizált, ellenőrzött klasztervizsgálata (WAVES vizsgálat)
}

\author{
Article review: Effectiveness of a childhood obesity prevention programme \\ delivered through schools, targeting 6 and 7 year olds: cluster randomised \\ controlled trial (WAVES study)
}

Ismertető: $\quad$ Erdei Gergő $₫$

Országos Gyógyszerészeti és Élelmezés-egészségügyi Intézet

\begin{abstract}
Ismertetett cikk: Peymane Adab, Miranda J Pallan, Emma R Lancashire et al. Effectiveness of a childhood obesity prevention programme delivered through schools, targeting 6 and 7 year olds: cluster randomised controlled trial (WAVES study). BMJ. 2018;360:k211 DOI: $10.1136 / \mathrm{bmj} . j 3984$
\end{abstract}

Beküldve: $\quad$ 2018. 10. 24.

doi: $\quad 10.24365 /$ ef.v59i6.371

Kulcsszavak: gyermek; elhízás; iskola; prevenció; testtömegindex

Keywords: child; obesity; school; prevention; body mass index

\begin{abstract}
A közleményben ismertetett WAVES vizsgálat célja az volt, hogy értékelje az egészséges életmódra irányuló iskolai és családi programokat a gyermekkori elhízás megelőzésére gyakorolt hatásuk alapján. A vizsgálatban 54 iskola 1392 (kontrollminta $n=732$ ) tanulója vett részt. Az intervenció időtartama 12 hónap volt, amely alatt a tanulók és családjuk az egészséges táplálkozás és a rendszeres fizikai aktivitás elméleti és gyakorlati elemeivel ismerkedhettek meg. A kutatók azt feltételezték, hogy az intervenciós és a kontrollcsoport testtömegindexe (BMI) között különbséget fognak találni a vizsgálat 15 . és 30 . hónapja között. A vizsgálat másodlagos kimenetelében azt várták, hogy további antropometriai, táplálkozási, fizikai aktivitásbeli és pszichológiai különbségeket fognak azonosítani.

A vizsgálat indulásakor 54 iskola 1392 tanulójának testtömegét mérték meg, majd 15 hónap múlva 53 iskola 1249 tanulóját, ezt követően pedig a
\end{abstract}

30. hónapban 53 iskola 1145 tanulóját mérték. A vizsgálat 15. [átlagos különbség: $-0,075$ (95\% Cl: $-0,183 ; 0,033) p=0,18$ ] és 30. [átlagos különbség: $-0,027$ (95\% Cl: $-0,137 ; 0,083) p=0,63$ ] hónapjában sem találtak szignifikáns eltérést a kontrollcsoport és az intervenciós csoport BMI-je között. A vizsgálatban nem tudtak szignifikáns különbséget azonosítani más antropometriai, táplálkozási, fizikai aktivitásbeli és pszichológiai mérések eredményei esetében sem.

Jelen vizsgálat eredményei azt mutatják, hogy a tapasztalati tanulásra fókuszáló beavatkozásnak nem volt statisztikailag szignifikáns hatása a BMI-re vagy a gyermekkori elhízás megelőzésére. Eredményeik szerint az iskolák önmagukban valószínúleg nem elég hatékonyak a gyermekkori elhízás visszaszorításában, hiszen az eredményes beavatkozáshoz több szektorban és számos környezeti tényezőben szükséges beavatkozni. 


\section{TANULSÁGOK A HAZAI SZAKEMBEREK SZÁMÁRA}

Több szisztematikus áttekintés is azt sugallja, hogy az iskola alapú beavatkozások hatékonyak lehetnek a gyermekkori elhízás megelőzésében, azonban a jelen közlemény adatai alapján az iskolai oktatást ki kell egészíteni szélesebb körben tett beavatkozásokkal a hatékonyság növeléséhez. 